\title{
Effect of restricted-feeding strategies on blood concentrations of hormones, metabolites, and minerals in Holstein $\times$ Zebu finishing steers
}

\section{Efeitos de diferentes estratégias de restrição alimentar sobre as concentrações de hormônios, metabólitos e minerais de machos Holandês × Zebu não castrados em terminação}

Flávia Adriane de Sales Silva1* (D) , Sebastião De Campos Valadares Filho ${ }^{1}$ (D) , Luciana Navajas Rennó ${ }^{1}$ (D) , Nathalia Veloso Trópia ${ }^{1}$ (D) , Caio William Magalhães Souza ${ }^{1}$, Herlon Meneguelli Alhadas ${ }^{1}$ (D) , Erica Garcia Mafort ${ }^{1}$ (D) , Tara Louise Felix² (D)

${ }^{1}$ Universidade Federal de Viçosa, Viçosa, MG, Brazil.

2Department of Animal Science, Pennsylvania State University, University Park, Pennsylvania, USA.

*Correspondent - flavia.sales@ufv.br

\section{Section: Zootecnia \\ Received \\ March 6, 2020 \\ Accepted \\ August 12, 2020. \\ Published \\ October 19, 2020}

www.revistas.ufg.br/vet

visit the website to get the how to cite in the article page.

\begin{abstract}
The objectives were to determine the effects of restrictedfeeding strategies on blood concentrations of hormones, metabolites, and minerals in Holstein $\times$ Zebu finishing steers. Twenty steers (body weight $=319 \pm 16.2 \mathrm{~kg}$; age $=19$ \pm 1 months) were randomly allotted in 4 groups of 5 steers, which were restricted to $85 \%$ ad libitum feed intake for either 0 (R0; $n=5), 28$ (R28; $n=5), 42(R 42 ; n=5)$ or $84(R 84 ; n=$ 5 ) days of an 84-d finishing period. Steers were individually housed and considered the experimental unit. Blood samples were collected on d 0, 21, 42, 63, and 84, and were assayed for insulin-like growth factor 1 (IGF-1), thyroid hormones (T3 and T4), albumin, creatinine, urea, total protein, glucose, triglycerides, calcium, and phosphorus. Steers had increasing IGF-1 concentrations until d 42 when restricted-fed. Steers fed R84 had the greatest IGF-1 concentrations on d 84. Urea concentrations were greatest in steers fed R0 and least in steers fed R28; steers fed R42 and R84 were intermediate and not different from one another. Concentrations of IGF-1, urea, albumin, and calcium, but not T3, T4, glucose, triglycerides, creatinine, total protein, and phosphorus were affected by restricted-feeding strategies in Holstein $\times$ Zebu finishing steers.
\end{abstract}

Keywords: Crossbred Cattle; Mineral Balance; Restricted Intake

\section{Resumo}

Objetivou-se avaliar os efeitos de diferentes estratégias de alimentação restrita sobre as concentrações sanguíneas de hormônios, metabólitos e minerais de machos Holandês $x$ Zebu castrados em terminação. Vinte machos Holandês $\times$ Zebu castrados (peso corporal inicial $[P C]=319 \pm 16,2 \mathrm{~kg}$; idade = $19 \pm 1$ meses) foram aleatoriamente distribuídos em 4 grupos de 5 animais, os quais receberam alimentação restrita a $85 \%$ do consumo ad libitum por 0 (R0; $n=5), 28$ (R28; $n=5), 42(R 42 ; n=5)$ ou $84(R 84 ; n=5)$ dias. Os animais foram alojados individualmente e considerados como unidades 
experimentais. Amostras de sangue foram coletadas nos dias 0, 21, 42 e 84, e analizadas quanto às concentrações de fator de crescimento semelhante à insulina 1 (IGF-1), hormônios tireiodianos (T3 e T4), albumina, creatinina, ureia, proteína total, glicose, triglicerídeos, cálcio e fósforo. Animais que receberam alimentação restrita apresentaram aumento nas concentrações de IGF-1 até o dia $42(P<0,05)$. Animais R84 apresentaram as maiores $(P<0,05)$ concentrações de IGF-1 no dia 84. As concentrações de ureia foram maiores $(P<0,05)$ para os animais AL84 e menores $(P<0,05)$ para os animais R28; os animais R42 e R84 apresentaram valores intermediários e não diferentes $(P>0,05)$ entre si. As concentrações de IGF-1, ureia, albumina, e calcium, mas não as de T3, T4, glicose, triglicerídeos, creatinina, proteína total e fósforo, foram influencias pelas diferentes estratégias de alimentação restrita utilizadas em machos Holandês $\times$ Zebu castrados em terminação.

Palavras-chave: Balanço Mineral; Bovinos Cruzados; Consumo Alimentar Restrito

\section{Introduction}

Restricted-feeding is defined as providing feed in amounts less than the predicted ad libitum intake ${ }^{(1)}$. In most cases, cattle that are restricted-fed during a growing phase experience compensatory growth (CG) when subsequently fed ad libitum during the finishing phase ${ }^{(2-4)}$. It is believed CG occurs due to the early physiological adaptation to feed restriction(5). However, the occurrence, magnitude, and persistence of physiological adaptations after a return to ad libitum feeding are variable and depend on factors such as breed, gender, diet, stage of maturity, and the degree and duration of feed restriction ${ }^{(5-7)}$. Thus, the exact physiological mechanisms of CG are still not fully understood.

The physiological mechanisms in cattle undergoing CG have been evaluated(8-10). However, severe (from 43 to $55 \%$ of ad libitum DM intake) and/or long periods (from 95 to $188 \mathrm{~d}$ ) of feed restriction were used in these studies. In most studies, cattle that were restricted-fed in the growing phase had impaired growth performance and carcass characteristics or required additional time on feed to reach market weight, when compared to those that were continuously fed ad libitum $(3,4,11)$. Thus, data suggest restricted-feeding may not be advisable in practical conditions.

In contrast, it has been observed in an accompanying study that a moderate feed restriction (15\% of ad libitum DM intake) reduced feed intake, but did not impair growth performance or carcass characteristics of Holstein $\times$ Zebu finishing steers, even when steers were restricted-fed for the entire finishing phase $(84 \mathrm{~d})^{(12)}$. Thus, we hypothesized that increased duration of restricted-feeding would result in greater magnitude and persistence of physiological responses experienced by Holstein $\times$ Zebu finishing steers restricted-fed to $85 \%$ of ad libitum DM intake. Therefore, our objectives 
were to evaluate the effect of restricted-feeding strategies on blood concentrations of hormones, metabolites, and minerals associated with growth metabolism in Holstein $\times$ Zebu finishing steers over time.

\section{Material and Methods}

Care procedures for the steers during the experiment followed the protocols approved by the rules of the Ethics Committee on Farm Animal Use under the protocol number $12 / 2016$.

Twenty Holstein $\times$ Zebu steers (average age $=19 \pm 1$ months; average initial body weight $[\mathrm{BW}]=319 \pm 16.2 \mathrm{~kg}$ ) were used in this study. Steers were contemporaneous and came from the same farm. Before the trial, all steers were raised in a pasture system with nutrient supplementation. The experiment was a completely randomized design and lasted $112 \mathrm{~d}$ with $28 \mathrm{~d}$ for the steers to adapt to the location and diets, and $84 \mathrm{~d}$ of data collection. The steers were housed in $6 \mathrm{~m}^{2}$ individual covered pens with concrete floors that were equipped with individual feeders and continuous flow concrete drinkers. The average air temperature, humidity, and precipitation during the trial were $18^{\circ} \mathrm{C}, 79 \%$, and $7 \mathrm{~mm}$, respectively.

At the end of the adaptation period, the steers were weighed after a 14-h fasting period, and were randomly assigned to 1 of 4 treatments $(n=5$ steers per treatment): ad libitum-fed for $84 \mathrm{~d}(\mathrm{R} 0)$, restricted-fed for first $28 \mathrm{~d}$ (R28), restricted-fed for first 42 d (R42), or restricted-fed for $84 \mathrm{~d}$ (R84). Steers fed R28, R42, and R84 were fed to 85\% of ad libitum, based on R0 steers DM intake (DMI), during the respective restrictedfeeding periods. Steers fed R28 and R42 were then provided ad libitum access to feed for the remainder of the finishing period, by 56 and $42 d$, respectively.

The experimental diet was the same regardless of treatment. The diet was calculated according to the BR CORTE recommendations ${ }^{(13)}$ to provide approximately $11 \%$ crude protein (CP) on a DM basis. The diet contained $40 \%$ corn silage and $60 \%$ of a concentrate mix (DM basis). The concentrate was formulated with ground corn, soybean meal, urea, ammonium sulfate, sodium bicarbonate, magnesium oxide, salt, limestone, and a mineral mixture (Table 1).

The corn silage and the concentrate were weighed separately and then hand mixed at the time of feeding. The total mixed ration was provided once a day $(0800 \mathrm{~h})$ and the steers had free access to clean water. The diet for ad libitum-fed steers was adjusted daily for refusals of approximately $2 \%$ of the offered total on an as-fed basis, and orts were mixed with the new feed that was offered the next day. The steers were weighed every $14 \mathrm{~d}$ to monitor average daily gain (ADG) and to adjust the DMI of restrictedfed steers. Additional information regarding the experimental procedures of the current study, and the effect of treatments on DMI, BW, ADG, feed efficiency, carcass characteristics, and non-carcass components growth were previously described by Silva et al. ${ }^{(12)}$. 
Three blood samples were collected from individual steers on d 0,21,42, 63, and 84. Blood samples were collected by a jugular venous puncture at $0700 \mathrm{~h}$, before feeding. Two of the samples were collected in $8.5 \mathrm{~mL}$ tubes with clot activator and gel for serum separation (BD Vacutainer® SST II Plus, São Paulo, Brazil) for analysis of total triiodothyronine (T3), total thyroxine (T4), insulin-like growth factor 1 (IGF1), albumin, urea, total protein, creatinine, triglycerides, phosphorus (P), and calcium (Ca). The third sample was collected in a $6 \mathrm{~mL}$ tube with EDTA and sodium fluoride (BD Vacutainer ${ }^{\circledR}$ Fluoreto/EDTA, São Paulo, Brazil) for glucose analysis. After collection, the samples were centrifuged at 3,600 $\times \mathrm{g}$ for $15 \mathrm{~min}$ at $4^{\circ} \mathrm{C}$, and then serum and plasma were transferred to $2 \mathrm{~mL}$ microcentrifuge tubes and immediately frozen at $-80^{\circ} \mathrm{C}$ until further analysis.

Table 1. Composition of diet offered in both restricted and ad libitum-feeding periods

\begin{tabular}{|c|c|}
\hline Item & $\%$ Dry matter \\
\hline \multicolumn{2}{|l|}{ Diet composition } \\
\hline Corn Silage & 40.0 \\
\hline Ground corn & 53.6 \\
\hline Soybean meal & 3.60 \\
\hline Urea & 0.90 \\
\hline Ammonium sulfate & 0.10 \\
\hline Sodium bicarbonate & 0.75 \\
\hline Magnesium oxide & 0.25 \\
\hline Mineral mixture ${ }^{a}$ & 0.13 \\
\hline Salt (NaCl) & 0.30 \\
\hline Limestone $\left(\mathrm{CaCO}_{3}\right)$ & 0.42 \\
\hline \multicolumn{2}{|l|}{ Chemical composition } \\
\hline Dry matter & 43.5 \\
\hline Organic matter & 94.2 \\
\hline Crude protein & 11.0 \\
\hline Ether extract & 2.95 \\
\hline Neutral detergent fiber ${ }^{b}$ & 27.6 \\
\hline Non-fiber carbohydrates & 54.3 \\
\hline Calcium & 0.32 \\
\hline Phosphorus & 0.30 \\
\hline
\end{tabular}

Serum concentrations of total T3 and T4 were determined on d 21, 42, 63, and 84. Total T3 and T4 were analyzed by chemiluminescence immunoassay using kits from Beckman Coulter (ref. numbers 33830 and 33800, respectively; Beckman Coulter ${ }^{\circledR}$, Brea, USA), in the Access 2 Immunoassay System (Beckman Coulter Inc., Brea, USA). Insulin-like growth factor 1 was quantified using kits DiaSorin (ref. number 313231; DiaSorin ${ }^{\circledR}$, Saluggia, Italy) on automated chemiluminescence analyzer (Liaison ${ }^{\circledR}$, Saluggia, Italy). 
Plasma concentrations of glucose were measured using a kit (ref. number K082) from Bioclin Diagnostics (Bioclin, Quibasa Química Básica Ltda, Belo Horizonte, Brazil). Serum concentrations of triglycerides (ref. number K117), urea (ref. number K056), total protein (ref. number K031); creatinine (ref. number K067), and albumin (ref. number K040) were measured using kits from Bioclin Diagnostics (Bioclin ${ }^{\circledR}$ Quibasa Química Básica Ltda, Belo Horizonte, Brazil). Serum concentrations of Ca (ref. number K051) and P (ref. number K068) were quantified using kits from Bioclin Diagnostics (Bioclin ${ }^{\circledR}$ Quibasa Química Básica Ltda, Belo Horizonte, Brazil). These metabolites and minerals previously described were analyzed following the manufacturer's instructions in an automatic biochemistry analyzer (Mindray BS200E, Shenzhen Mindray Bio-Medical Electronics Co. Ltd., Shenzhen, China).

Blood concentration data for hormones, metabolites, and minerals were analyzed in a completely randomized design by PROC MIXED procedures in SAS (version 9.4, SAS Institute Inc., Cary, NC, USA). Treatment and sampling day, as well as their interaction, were fixed effects in the model. Repeated measures were used to analyze the sampling day. The covariance structure was chosen based on the lowest corrected Akaike information criterion (AICC) for models run under compound-symmetry, heterogeneous compoundsymmetry, first-order autoregressive, banded main diagonal, or unstructured variancecovariance structures. The degrees of freedom were estimated by the Kenward-Roger method. Individual steers were the experimental units. Blood concentrations of the hormone, metabolite, or mineral on d 0 were used as covariates, except for total T3 and T4, urea, and Ca concentrations, because they were not significant for urea and Ca concentrations, and no data were available on d 0 for total T3 and T4 concentrations. Means were compared using Fisher's least significant difference test (LSD). Significance was declared at $\mathrm{P} \leq 0.05$, and tendencies were considered at $0.05<\mathrm{P} \leq 0.10$.

\section{Results}

There were treatment $\times$ day interactions $(P \leq 0.05)$ for IGF-1 (Figure $1 \mathrm{a}$ ) and Ca (Figure 1b) concentrations. The IGF-1 values (Figure 1a) were different among sampling days $(P<0.02)$ for all treatments, except for steers fed RO $(P \geq 0.36)$. Steers had increasing IGF-1 concentrations until d 42 ( $P<0.05)$ when restricted-fed. Meanwhile IGF-1 concentrations were more variable on $d 63$ and 84. Nevertheless, differences $(P<0.05)$ among treatments within sampling day were only observed on $d 84$, where IGF-1 levels were greatest $(P<0.05)$ in steers fed R84, and least in steers fed R0 and R28; steers fed R42 were intermediate and not different $(P>0.05)$ from the other treatments.

There were no differences $(P \geq 0.34)$ among treatments for Ca concentrations on $\mathrm{d} 0$, 21, and 42 (Figure $1 \mathrm{~b}$ ). However, Ca concentrations were greater $(P<0.05)$ in steers fed R0, R28, and R42 compared to steers fed R84 on d 63. On d 84, greater $(P<0.05) \mathrm{Ca}$ concentrations were observed for steers fed R0 and R28 compared to steers fed R42 and R84.

There was a tendency for treatment $x$ day interaction $(P \leq 0.08)$ for $P$ concentrations 
(Figure 1c). On $\mathrm{d} 63$, P values tended to be greatest $(P<0.10)$ in steers fed R42 and least in steers fed R28; steers fed R0 and R84 tended to be intermediate and not different $(P>0.10)$ from the other treatments (Figure $1 c)$. In addition, on d 84, P concentrations tended to be greatest $(P<0.10)$ in steers fed R84 and least in steers fed R28; steers fed R0 and R42 tended to be intermediate and not different $(P>0.10)$ from the other treatments.

No treatment $x$ day interactions $(P \geq 0.13$ ) were observed for total T3 (Figure 2a) and T4 (Figure 2b), glucose (Figure 2c), triglycerides (Figure 2d), urea (Figure 3a), creatinine (Figure 3b), albumin (Figure 3c), or total protein (Figure 3d). No main effect of treatment or day was observed $(P \geq 0.23)$ for total T3 (Figure $2 a)$, creatinine (Figure 3b), triglycerides (Figure $2 \mathrm{~d}$ ), or total protein (Figure $3 \mathrm{~d}$ ) concentrations.

Urea concentrations were greatest $(P<0.05)$ in steers fed R0 and least $(P<0.05)$ in steers fed R28; steers fed R42 and R84 were intermediate and not different $(P>0.05)$ from one another (Figure 3a). Albumin concentrations were greatest $(P<0.05)$ in steers fed R42 and R84, and least in steers fed R0; steers fed R28 were intermediate and not different $(P>0.05)$ from the other treatments (Figure $3 c)$. While there was no main effect of treatment on glucose and total T4 concentrations ( $P \geq 0.14)$, there was a main effect of day ( $P \leq 0.01$ ) for levels of glucose (Figure $2 c$ ) and total T4 (Figure 2b). Glucose concentrations were not different $(P>0.05)$ on $d 0,21$, and 42 , but increased on $d 84$ ( $P$ $<0.05)$, regardless of treatment. Glucose concentration on d 63 was intermediate and not different from other days $(P>0.05)$. Greater $(P<0.05)$ concentrations of total T4 were observed on $\mathrm{d} 21$ and 42 compared to $\mathrm{d} 63$ and 84 , regardless of treatment. 
Effect of restricted-feeding strategies on blood concentrations of hormones, metabolites, and minerals... Silva F.A. de S. et al..

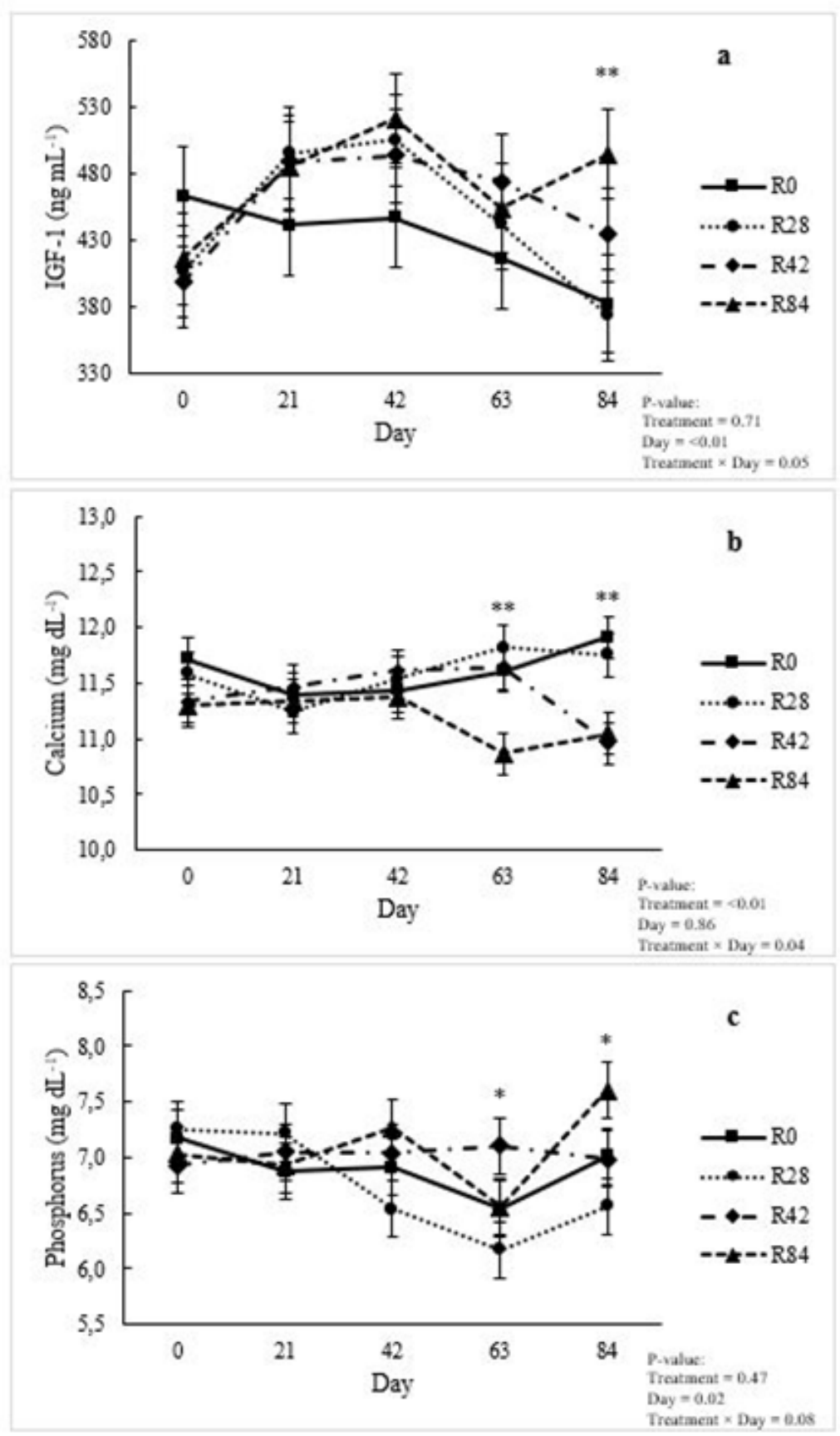

Figure 1. Effect of treatments on concentrations of insulin-like growth factor 1 (IGF-1; a), Calcium (b), and Phosphorus (c) of Holstein $\times$ Zebu finishing steers. Treatments: R0 = Steers fed for ad libitum-intake for 84 d; R28 = Steers restricted (intake restricted to 8596 of ad libitum DM intake [DMI], based on Ro steers intake of the last $3 \mathrm{~d}$ ) for $\mathbf{2 8} \mathrm{d}$ then fed for ad libitum-intakes for $56 \mathrm{~d}$; R42 = Steers restricted for $42 \mathrm{~d}$ then fed for ad libitum-intakes for $42 \mathrm{~d}$; R84 = Steers restricted for $84 \mathrm{~d}$. There were effects of treatment $\times$ day interactions ( $P \leq 0.05$ ) for IGF-1 and calcium concentrations ( $A$ and $B$ ). There was a tendency for treatment $x$ day interaction $(P \leq 0.08)$ for $P$ concentrations $(C)$ * * Treatment $x$ day interaction means differ $(P \leq 0.05)$. *Treatment $x$ day interaction means differ $(P \leq 0.08)$. Error bars represent the standard error of the mean associated to the interaction between treatment and day (SEM = 37.3 for IGF-1; SEM = 0.19 for calcium; $\mathrm{SEM}=0.25$ for phosphorus). 
Effect of restricted-feeding strategies on blood concentrations of hormones, metabolites, and minerals.. Silva F.A. de S. et al.

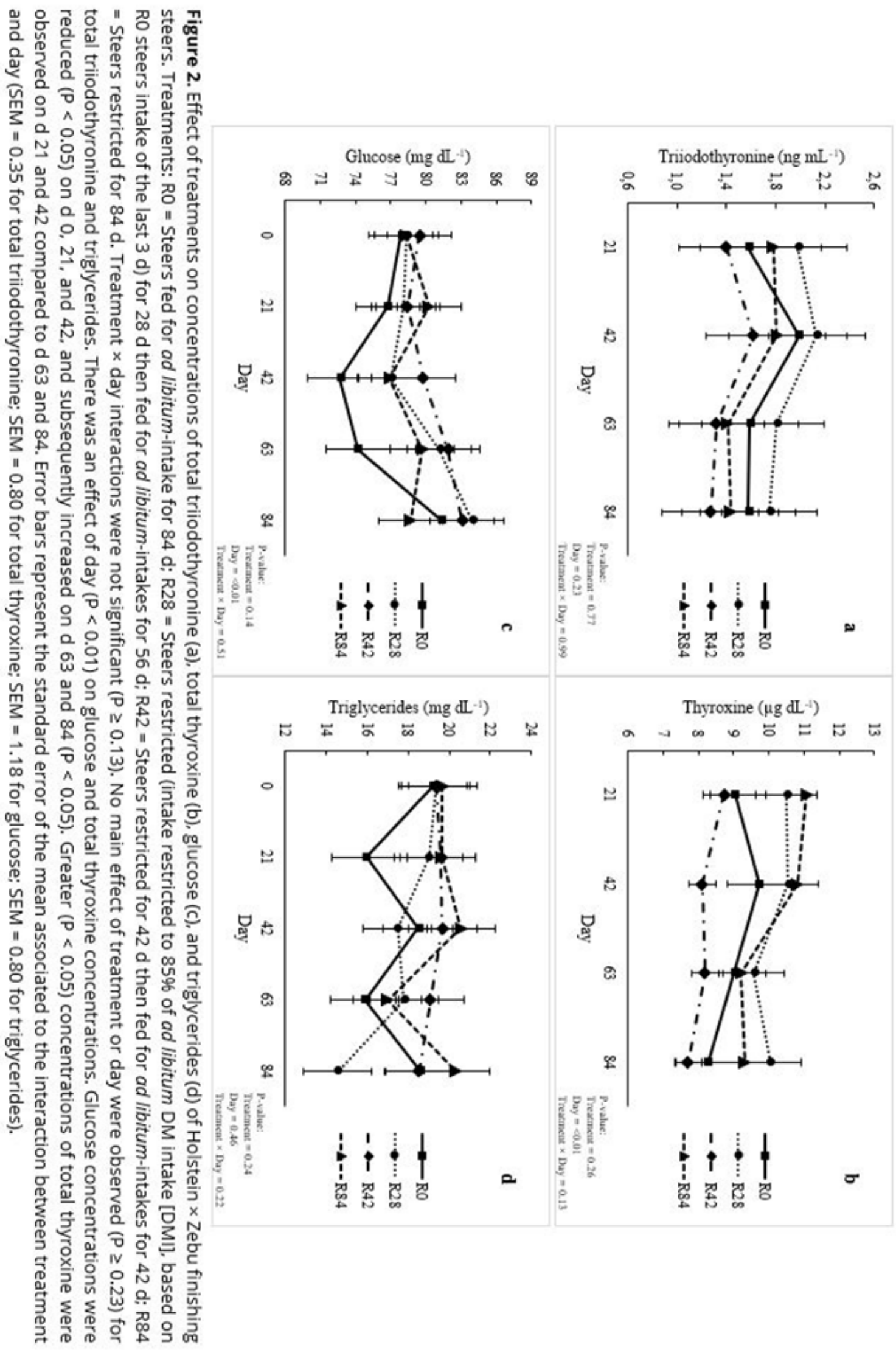


Effect of restricted-feeding strategies on blood concentrations of hormones, metabolites, and minerals... Silva F.A. de S. et al..

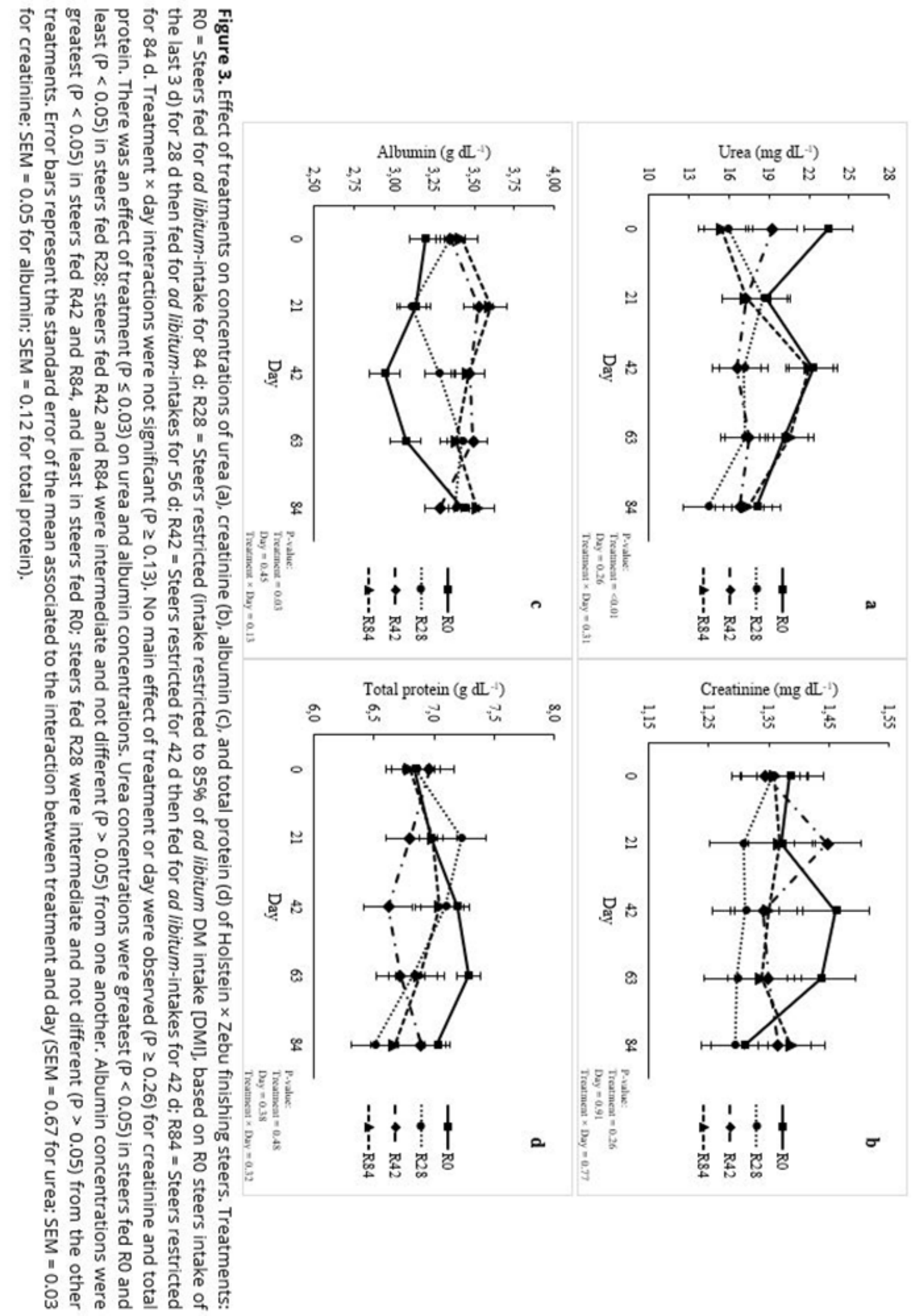




\section{Discussion}

Hormone, metabolite, and mineral blood concentrations reflect an animal's nutritional status $^{(8)}$. Thus, alterations in their concentrations are expected during the restrictedfeeding period in ruminants, as a response to reduced feed intake, because the animal is attempting to maintain homeostasis ${ }^{(5,14)}$. The alteration may be reversed within days after the return to ad libitum feeding, depending on the severity and duration of restricted-feeding $(8,10,15)$.

For example, decreased levels of glucose, thyroid hormones, and IGF-1 have been reported in restricted-fed cattle $(8,10,16)$, as a result of reduced feed intake. Researchers theorize this response is an attempt to reduce basal metabolism and energy expenditure and change the preferential utilization of substrates to maintain homeostasis, rather than stimulate growth ${ }^{(17,18)}$. Greater transient (at the beginning of restricted-feeding period) or sustained (during the whole restricted-feeding period) concentrations of nonesterified fatty acids, beta-hydroxybutyrate, urea, creatinine, albumin, and total protein have also been reported during restricted-feeding $(9,10,15)$. These researches suggested adipose and protein mobilization occurred to overcome energy deficit when cattle were restricted-fed from 43 to 55\% of ad libitum DMI from 95 to $180 d^{(9,10,15)}$.

However, our results did not follow the same pattern. No treatment $\times$ day interactions were observed for any of the metabolites evaluated. In addition, no treatment effect was observed for concentrations of glucose, triglycerides, creatinine, total protein, or total T3 and T4; and IGF-1 levels were not reduced during the restricted-feeding period in steers that were restricted. Our results suggest that the 15\% DMI feed restriction imposed in the current study was not severe enough to reduce basal metabolism or impair growth stimulus.

Current data may conflict with previous research because, despite the reduced DMI, steers continued to grow, albeit at a slightly reduced rate $\left(1.40 \mathrm{vs.} 1.30 \mathrm{~kg} \mathrm{~d}^{-1}\right)$, during the restricted-feeding periods ${ }^{(12)}$. In the studies previously described, when cattle were severely restricted, feed intake was just maintaining $\mathrm{BW}^{(9,16)}$ or supporting minimal growth (from 0.12 to $\left.0.6 \mathrm{~kg} \mathrm{~d}^{-1}\right)^{(8,10,15)}$, whereas steers of the current study presented an ADG of approximately $1.30 \mathrm{~kg} \mathrm{~d}^{-1}$ during restricted-feeding periods ${ }^{(12)}$.

Duration of restricted-feeding affected overall concentrations of urea and albumin. Urea concentration is an indicator of protein status in cattle, as it is positively associated with nitrogen $(\mathrm{N})$ intake and protein turnover $(19,20)$. All steers in the current study were fed the same diet; thus, $\mathrm{N}$ intakes differed among treatments, as DMI was assigned according to treatment. Therefore, the greatest urea concentrations observed in steers fed R0 compared to steers fed R28, R42, and R84 were due to greater dietary N intake ${ }^{(12)}$.

On the other hand, the reduction in overall urea values observed in steers fed R28, R42, and $\mathrm{R} 84$ relative to steers fed R0 could also be attributed to increased $\mathrm{N}$ use efficiency when steers were restricted-fed $(5,10,15)$. In addition, among restricted-fed steers, the lowest overall urea concentrations were observed for steers fed R28 compared to steers fed 
R42 and R84, suggesting that N use efficiency was greatest when cattle were restricted only a short time. The fact that overall growth performance and carcass characteristics were not impaired even when steers were restricted-fed for the entire finishing phase (84 d), and steers fed R28 experienced the greatest whole-body $\mathrm{N}$ retention among all treatments ${ }^{(12)}$, suggests that increased $\mathrm{N}$ efficiency occurred in the restricted-fed steers.

Albumin levels also serve as an indicator of protein status in cattle ${ }^{(21,22)}$. In this study, albumin concentrations increased as the duration of restricted-feeding increased, and the greatest concentrations were observed when steers were restricted-fed for 42 and $84 \mathrm{~d}$. Keogh et al.(10) observed increased albumin concentrations during the initial stages of feed restriction in Holstein-Friesian bulls. The authors of this study postulated that their results reflected the utilization of protein from body reserves to bridge an animal's energy deficits. However, as discussed previously, feed restriction imposed in the current study was not severe enough to cause a negative energy balance, regardless of the duration of the restriction. Thus, in this study, increased protein catabolism to meet an animal's energy requirements does not explain the increased overall albumin values in restricted-fed steers compared to steers fed for ad libitum intake. Nevertheless, the authors are not aware of any study that has associated increased albumin concentrations with increased protein anabolism.

Insulin-like growth factor 1 is a well-characterized in promoting muscle growth ${ }^{(17}$, 18). The serum concentration of IGF-1 is directly associated with nutritional status in ruminants. Thus, it rises with increased feed intake and falls with feed restriction ${ }^{(23,24)}$. Reduction in circulating IGF-1 levels during a period of feed restriction has previously been reported in heifers $s^{(9,25)}$, steers ${ }^{(8,15)}$, and bulls $s^{(3,10)}$. This effect of feed restriction was reversed within days after the return to ad libitum feeding. However, in the current study, $15 \%$ of DMI feed restriction did not reduce IGF-1 concentrations, regardless of the duration of the restriction. On the contrary, IGF-1 concentrations increased as the length of restriction increased, suggesting that IGF-1 production is stimulated when moderate restricted-feeding is used. After access to ad libitum feed was granted, IGF-1 concentrations gradually returned to d 0 values in steers fed R28. However, on d 84, IGF-1 concentrations remained greater $(P<0.05)$ in steers fed R42 compared to $d 0$ and steers fed R0 levels, and steers restricted during the entire $84 \mathrm{~d}$ period (R84) had the greatest IGF-1 concentrations.

Stimulation in muscle cells by IGF- 1 results in increased uptake of amino acids and glucose, satellite cell proliferation, and protein synthesis, in addition to decreased proteolysis and apoptosis ${ }^{(17,18,26)}$. Thus, reduced urea concentrations in combination with increased IGF-1 concentrations in restricted-fed steers indicate IGF-1 may be improving $\mathrm{N}$ conservation and improving muscle accretion.

Unlike most previous studies, the effect of duration of restricted-feeding on $\mathrm{Ca}$ and $\mathrm{P}$ concentrations were also evaluated in the current study. Calcium and P concentrations are tightly regulated through homeostatic mechanisms ${ }^{(27,28)}$. Thus, except in extreme cases, $\mathrm{Ca}$ and $\mathrm{P}$ serum concentrations are maintained relatively constant, between 9 
to 11 and 6 to $8 \mathrm{mg} \mathrm{dL}^{-1}$, respectively ${ }^{(29,30)}$, which makes interpreting dietary treatment effects in their blood concentrations difficult.

The diet used in the current study supplied about 32 and $26 \mathrm{~g} \mathrm{~d}^{-1}$ of Ca when steers were ad libitum and restricted-fed, respectively. The diet supplied 30 and $25 \mathrm{~g} \mathrm{~d}^{-1} \mathrm{P}$ when steers were ad libitum and restricted-fed, respectively. According to BR CORTE(13), the daily requirements of Holstein $\times$ Zebu finishing steers at $319 \mathrm{~kg}$ of average BW and ADG of $1.38 \mathrm{~kg} \mathrm{~d}^{-1}$ (the average of the steers in this study) is 32.13 and $19.29 \mathrm{~g} \mathrm{~d}^{-1}$ of Ca and $P$, respectively. Thus, despite the reduced DMI, the $P$ supply was about $5.7 \mathrm{~g}$ above daily requirements; however, steers had a daily deficit of about $6 \mathrm{~g}$ of Ca during the restricted-feeding period. Despite the insufficient dietary supply Ca when steers were restricted-fed, Ca levels remained within the normal range for cattle ${ }^{(22,31)}$ throughout the experiment: 10.9 and $11.8 \mathrm{mg} \mathrm{dL}^{-1}$. This result is not surprising as homeostatic mechanisms to maintain circulating $\mathrm{Ca}$ concentrations are tightly regulated(32). This regulation likely decreased variation in $\mathrm{Ca}$ and $\mathrm{P}$ concentrations, increasing the significant differences when small numerical variations within and among treatments occurred.

Concentrations of glucose and total T4 did not differ among treatments. However, an effect of sampling day was observed for values of glucose and total T4, where steers from all treatments experienced increased glucose and decreased T4 concentrations on d 63 and 84. Increased levels of glucose close to the end of the experiment could be resulted in reduced insulin sensitivity as steers gained weight and became fatter ${ }^{(33,34)}$. Often, T4 concentrations are positively correlated with metabolic rate, and it is well known that metabolic rate decreases with advancing age or as animals reach maturity ${ }^{(35-37)}$. Feedlot production systems in developing countries are different than those used in developed countries. In the United States, for example, animals are confined between the ages of 7 to 16 months for 140 to $180 \mathrm{~d}$, on average(38). In Brazil, however, cattle are grown first for 18 to 21 months on pastures and then transferred to feedlots where they stay for only approximately 80 to $100 \mathrm{~d}$ and are slaughtered at 21 to 25 months $^{(39)}$. In the current study, steers were 19 months old at the start of the feedlot period, when bone tissue growth might be completed, and reasonable amounts of muscle tissues already deposited. That is, the steers were closer to maturity than cattle fed in US feedlot that are killed at 16 to 20 months of age. Thus, decreased T4 concentrations close to the end of the feedlot period may be a result of the natural aging and maturity process.

\section{Conclusions}

This study demonstrated the possible physiological mechanisms by which Holstein $x$ Zebu finishing steers adapted to moderate restricted-feeding strategies. Regardless of the duration of restricted-feeding (15\% DMI restriction), our results did not indicate a change in tissue mobilization to bridge energy deficit or reduction in basal metabolism and energy expenditure in Holstein $\times$ Zebu finishing steers. However, our results also suggested increased $\mathrm{N}$ use efficiency and improved muscle accretion when steers were 
Effect of restricted-feeding strategies on blood concentrations of hormones, metabolites, and minerals.. Silva F.A. de S. et al..

restricted-fed. This understanding may contribute to better feed management for cattle in feedlots.

\section{Acknowledgements}

This study and scholarship of the first author were supported by Conselho Nacional de Desenvolvimento Científico e Tecnológico (CNPQ, Brazil), Coordenação de Pessoal de Nível Superior (CAPES, Brazil), Fundação de Amparo à Pesquisa do Estado de Minas Gerais (FAPEMIG, Brazil), and Instituto Nacional de Ciência e Tecnologia em Ciência Animal (INCT - CA, Brazil). Thanks are also extended to the Department of Animal Science of Pennsylvania State University for the collaboration on the preparation of this manuscript.

\section{References}

1.Galyean ML. Review: Restricted and programmed feeding of beef cattle-definitions, application, and research results. PAS. 1999; 15:1-6.

2.Carstens GE, Johnson DE, Ellenberger MA, Tatum JD. Physical and chemical components of the empty body during compensatory growth in beef steers. J Anim Sci. 1991; 69:3251-64.

3.Hornick JL, Van Eenaeme C, Diez M, Minet V, Istasse L. Different periods of feed restriction before compensatory growth in Belgian Blue bulls: II. Plasma metabolites and hormones. J Anim Sci. 1998; 76:260-71.

4.Felix TL, Radunz AE, Loerch SC. Effects of limit feeding corn or dried distillers grains with solubles at 2 intakes during the growing phase on the performance of feedlot cattle. J Anim Sci. 2011; 89:2273-79.

5.Hornick JL, Van Eenaeme C, Gérard O, Dufrasne I, Istasse L. Mechanisms of reduced and compensatory growth. Domest Anim Endocrinol. 2000; 19:121-32.

6.Wilson PN, Osbourn DF. Compensatory growth after undernutrition in mammals and birds. Biol Rev. 1959; 35:324-61.

7.Mahyuddin, P. Compensatory growth in ruminants. Anim Prod. 2004; 6:125-35.

8.Ellenberger MA, Johnson DE, Carstens GE, Hossner KL, Holland MD, Nett TM, Nockels CF. Endocrine and metabolic changes during altered growth rates in beef cattle. J Anim Sci. 1989; 67:1446-54.

9.Yambayamba ES, Price MA, Foxcroft GR. Hormonal status, metabolic changes, and resting metabolic rate in beef heifers undergoing compensatory growth. J Anim Sci. 1996; 74:57-69.

10.Keogh K, Waters SM, Kelly AK, Wylie A RG, Sauerwein H, Sweeney T, Kenny DA. Feed restriction and realimentation in Holstein-Friesian bulls: II. Effect on blood pressure and systemic concentrations of metabolites and metabolic hormones. J Anim Sci. 2015; 93:3590-3601.

11.Keogh K, Waters SM, Kelly AK, Kenny DA. Feed restriction and subsequent realimentation in Holstein Friesian bulls: I. Effect on animal performance; muscle, fat, and linear body measurements; and slaughter characteristics. J Anim Sci. 2015; 93:3578-89.

12.Silva FAS, Valadares Filho SC, Godoi LA, Silva BC, Pacheco MVC, Zanetti D, Benedeti PDB, Silva FF, Felix TL. Effect of duration of restricted-feeding on nutrient excretion, animal performance, and carcass characteristics of Holstein $\times$ Zebu finishing steers. Anim Prod Sci. 2020; 60:535-544. 
Effect of restricted-feeding strategies on blood concentrations of hormones, metabolites, and minerals..

Silva F.A. de S. et al.

13.Valadares Filho SC, Costa e Silva LF, Gionbelli MP, Rotta PP, Marcondes MI, Chizzotti ML, Prados LF. Nutrient Requirements of Zebu and Crossbred Cattle - BR-CORTE. 3rd ed. Visconde do Rio Branco: Suprema Gráfica Ltda.; 2016. 314p. English.

14. Hoch T, Begon C, Picard B. Mécanismes et conséquences de la croissance compensatrice chez les ruminants. INRA Prod Anim. 2003; 16:49-59.

15. Hayden JM, Williams JE, Collier RJ. Plasma growth hormone, insulin-like growth factor, insulin, and thyroid hormone association with body protein and fat accretion in steers undergoing compensatory gain after dietary energy restriction. J Anim Sci. 1993; 71:3327-3338.

16.Blum J W, Schnyder W, Kunz PL, Blom AK, Bickel H, Schürch A. Reduced and compensatory growth: Endocrine and metabolic changes during food restriction and refeeding in steers. J Nutr. 1985; 115:41724.

17.Breier BH. Regulation of protein and energy metabolism by the somatotropic axis. Domest Anim Endocrinol. 1999; 17:209-18.

18. Hossner KL. Hormonal regulation of farm animal growth. Cambridge: CABI Publishing; 2005. 240p. English.

19.Preston R, Schnakenberg D, Pfander W. Protein utilization in ruminants: I. Blood urea nitrogen as affected by protein intake. J Nutr. 1965; 86:281-88.

20.Kohn RA, Dinneen MM, Russek-Cohen E. Using blood urea nitrogen to predict nitrogen excretion and efficiency of nitrogen utilization in cattle, sheep, goats, horses, pigs, and rats. J Anim Sci. 2005; 83:879-89.

21.Russell KE, Roussel AJ. Evaluation of the ruminant serum chemistry profile. Vet Clin North Am Food Anim Pract. 2007; 23:403-26.

22.Kaneko JJ, Harvey JW, Bruss ML. Clinical biochemistry of domestic animals. 6th ed. San Diego: Academic Press; 2008. 928p. English.

23.Bass JJ, Oldham JM, Hodgkinson SC, Fowke PJ, Sauerwein H, Molan P, Breier BH, Gluckman PD. Influence of nutrition and bovine growth hormone $(\mathrm{GH})$ on hepatic $\mathrm{GH}$ binding, insulin-like growth factor-I and growth of lambs. J Endocrinol. 1991; 128:181-86.

24.Mcguire MA, Vicini JL, Bauman DEP, Veenhuizent JJ. Insulin-like growth factors and binding proteins in ruminants and their nutritional regulation. J Anim Sci. 1992; 70:2901-10.

25. Ronge $\mathrm{H}$, Blum J. Insulin-like growth factor I responses to recombinant bovine growth hormone during feed restriction in heifers. Acta Endocrinol. 1988; 120:735-44.

26.Oksbjerg N, Gondret F, Vestergaard M. Basic principles of muscle development and growth in meatproducing mammals as affected by the insulin-like growth factor (IGF) system. Domest Anim Endocrinol. 2004; 27:219-240.

27. Rowlands GJ. A review of variations in the concentration of metabolites in the blood of beef and dairy cattle associated with physiology, nutrition and disease, with particular reference to the interpretation of metabolic profiles. World Rev Nutr Diet. 1980; 35:172-235.

28. Reinhardt TA, Horst RL, Goff JP. Calcium, phosphorus, and magnesium homeostasis in ruminants. Vet Clin North Am Food Anim Pract. 1988; 4:331-50.

29.NRC. Nutrient requirements of beef cattle. 7th ed. Washington: Nat. Acad. Press; 2000. 248p. English.

30.Berchielli TT, Pires AV, Oliveira SG. Nutrição de Ruminantes. 2nd ed. Jaboticabal: Editora Funep; 2011. $616 \mathrm{p}$. Portuguese. 
31.Doornenbal H, Tong AKW, Murray NL. Reference values of blood parameters in beef cattle of different ages and stages of lactation. Can J Vet Res. 1988; 52:99-105.

32.McDowell LR. Minerals in Animal and Human Nutrition. 2nd ed. Amsterdam: Elsevier; 2003. 660p. English.

33.Eisemann JH, Huntington GB, Catherman DR. Insulin sensitivity and responsiveness of portal-drained viscera, liver, hindquarters, and whole body of beef steers weighing 275 or 490 kilograms. J Anim Sci. $1997 ; 75: 2084-91$.

34.Radunz AE, Fluharty FL, Relling AE, Felix TL, Shoup LM, Zerby HN, Loerch S C. Prepartum dietary energy source fed to beef cows: II. Effects on progeny postnatal growth, glucose tolerance, and carcass composition. J Anim Sci. 2012; 90:4962-74.

35.Kleiber M. Body size and metabolic rate. Physiol Rev. 1947; 27:511-41.

36. Rolfe DFS, Brown GC. Cellular energy utilization and molecular origin of standard metabolic rate in mammals. Physiol Rev. 1997; 77:731-58.

37. Hulbert AJ, Pamplona R, Buffenstein R, Buttemer WA. Life and death: metabolic rate, membrane composition, and life span of animals. Physiol Rev. 2007; 87:1175-1213.

38.Samuelson KL, Hubbert ME, Galyean ML, Löest CA. Nutritional recommendations of feedlot consulting nutritionists: The 2015 New Mexico State and Texas Tech University survey. J Anim Sci. 2016; 94, 2648-63.

39.Ferraz JBS, Felício PE. Production systems - An example from Brazil. Meat Sci. 2010; 84:238-43. 